\title{
Behavior of Deep Beams using Different Concrete Grades
}

\author{
${ }^{1}$ Noha Ahmed Metwally Ahmed, ${ }^{2}$ Prof. Ayman Hussein Hosny Khalil, ${ }^{3}$ Dr. Ezz El-deen Mostafa \\ ${ }^{1,2,3}$ Structural Engineering Department, Faculty of Engineering, Ain Shams University, Egypt
}

\begin{abstract}
This paper presents the experimental results of the investigation of behavior of simply supported deep beams having layers of concrete of different grades $(25$ MPa and $50 \mathrm{MPa}$ ). The tested beams were loaded with one vertical load at mid span up to failure. All specimens were fabricated and tested at the laboratory of reinforced concrete of Faculty of Engineering, Ain Shams University. The experimental program is carried out using five simply supported deep beams having the same dimensions; specimens with an effective span of $1100 \mathrm{~mm}$, width of 200 mm and a height of $1000 \mathrm{~mm}$, specimens also have the same top, bottom, vertical, and horizontal reinforcement. The experimental studies showed that the failure of tested deep beams was mainly due to diagonal cracks. Casting concrete on different layers causes the first cracks appeared at earlier load than in beam with one grade of concrete. It was also found that the best flexural behavior of deep beams is obtained when the bottom layer is casted using high concrete compressive strength and gives results (deflection, and failure load) close to results of deep beam casted with high compressive strength.
\end{abstract}

Keywords: Deep beams, cracking pattern, Deflection, Experimental study, High compressive strength (HCS), Normal compressive strength (NCS).

\section{INTRODUCTION}

Reinforced concrete deep beams have many useful applications in buildings, bridge structures such as transfer girders, wall footings, foundation, floor diaphragms, bunkers, and tanks. The use of deep beams at lower levels in tall buildings for both residential and commercial purposes is well known [1-4]. A beam is considered deep beam, if the depth of beam is large with respect to span of beam. According to (ECP 203-2018) [5]; Deep beams have effective span to depth ratios smaller than 1.25 for the simple beams and 2.50 for the continuous beams. On the other hand, deep beam is defined according to ACI 318-19 [6]; a structural element with clear span equal to or less than four times the overall depth, or with applied concentrated loads that are within a distance equal to or less than two times the depth from the face of the support. The behavior of deep beam depends on its properties of materials and strength characteristics. Concrete plays a vital role in the development of deep beam and other structural elements where the deep beams made of high strength concrete (HSC) would show higher ability in resisting heavy loads than those made of normal strength concrete (NSC) [710].

As concrete is used to sustain compressive forces, it is essential that its strength and characteristics are determined and this has been studied in many previous researches, but the difference in this research is the study of the behavior of deep beams using different layers of various concrete compressive strengths and knowing the impact on its performance.

\section{OBJECTIVE AND SCOPE}

Behavior of deep beams depends on various parameters like compressive strength of concrete, shear reinforcement, shear span to depth ratio etc. In this paper, the cost reduction of concrete has been studied by studying the behavior of simply supported deep beams casted on different layers of concrete consisting of high strength concrete (HSC) and normal strength concrete (NSC), and comparing this behavior with deep beams which are casted using one compressive strength.

An experimental program is carried out for five simply supported deep beams with an effective span of $1100 \mathrm{~mm}$, width of $200 \mathrm{~mm}$ and a height of $1000 \mathrm{~mm}$. Specimens also share same top, bottom, vertical, and horizontal reinforcement. Specific objective of this research is Experimental Investigation of behavior of simply supported deep beams by using different layers of various concrete compressive strengths subjected to vertical loads at mid span such as (Cracking-deflection-ultimate loads).

\section{LABORATORY TESTING}

\subsection{Sample Configuration}

All five tested deep beams had the same dimensions. Specimens with an effective span of $1100 \mathrm{~mm}$, width of 200 $\mathrm{mm}$ and a height of $1000 \mathrm{~mm}$ as shown in Figure 1. Specimens also have same top, bottom, vertical, and horizontal reinforcement as shown in Figure 2. 
/

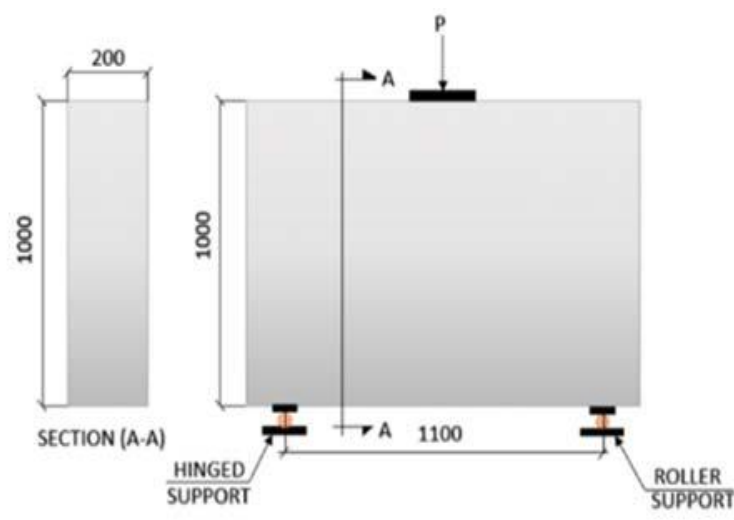

Figure 1: Specimen dimensions
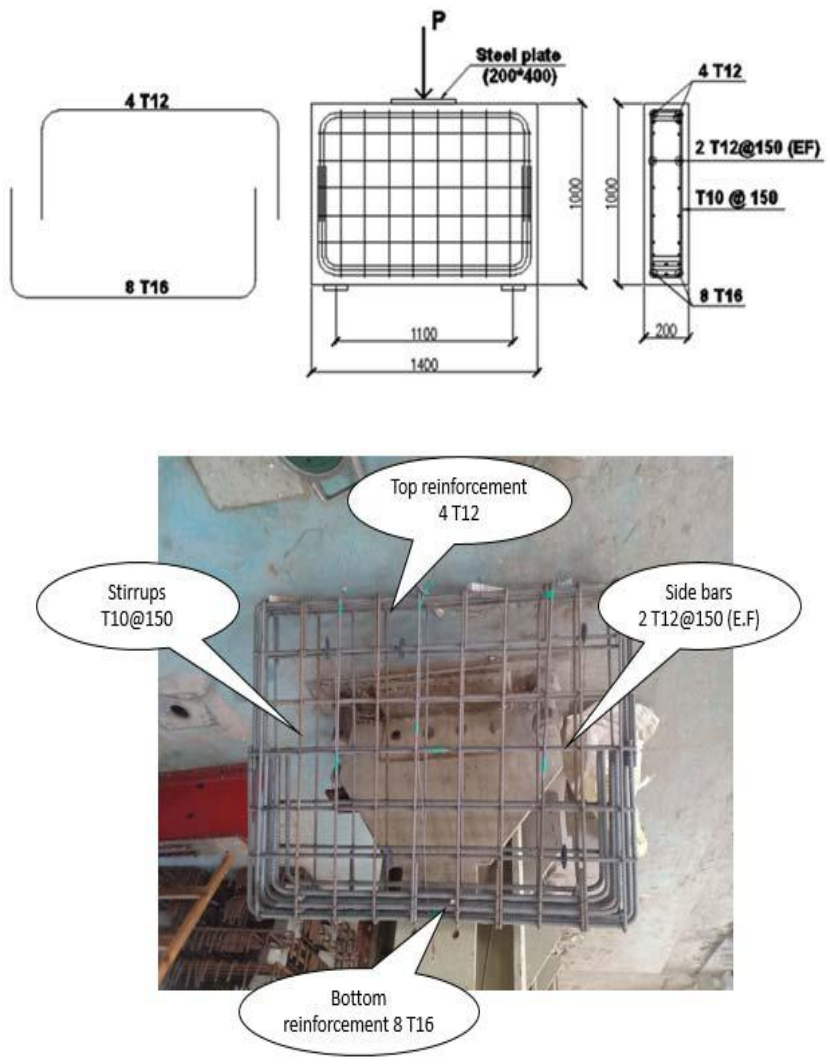

Figure 2: Reinforcement details of tested specimens

\subsection{Sample Parameters}

Different parameters and combinations were used to configure the five specimens to cover the studied variables; parameters can be summarized as below:

- Different concrete compressive cube strength $25 \mathrm{MPa}$ and $50 \mathrm{MPa}$.

Each specimen has a unique identification name indicating what parameters values are used in it. The description of each beam is summarized in Table 1:
ISSN (online): 2581-3048

Volume 5, Issue 8, pp 75-81, August-2021 https://doi.org/10.47001/IRJIET/2021.508013

Table 1: Properties of beam specimens and concrete strength

\begin{tabular}{|c|c|c|}
\hline Specimen & Layers & $\begin{array}{c}\text { Compressive } \\
\text { cube strength } \\
\mathrm{MPa}\end{array}$ \\
\hline B1 & 1 & 25 \\
\hline B2 & 1 & 50 \\
\hline \multirow{3}{*}{ B3 } & \multirow{3}{*}{3} & 25 \\
\hline & & 25 \\
\hline & & 50 \\
\hline \multirow{3}{*}{ B4 } & \multirow{3}{*}{3} & 50 \\
\hline & & 25 \\
\hline & & 50 \\
\hline \multirow{5}{*}{ B5 } & \multirow{5}{*}{5} & 50 \\
\hline & & 25 \\
\hline & & 25 \\
\hline & & 25 \\
\hline & & 50 \\
\hline
\end{tabular}

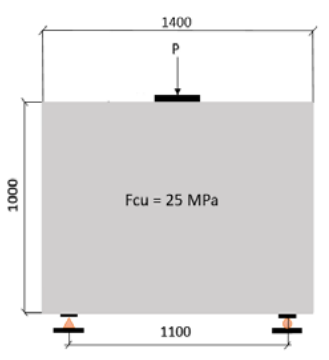

Figure 3-a: Specimen dimensions and compressive strength for (B1)

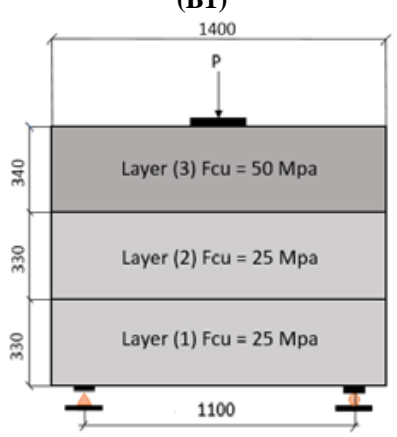

Figure 3-c: Specimen dimensions and compressive strength for (B3)

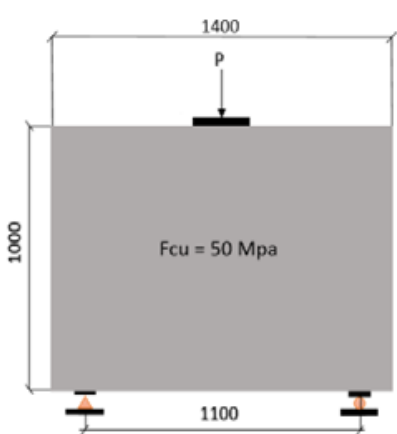

Figure 3-b Specimen dimensions and compressive strength for (B2)

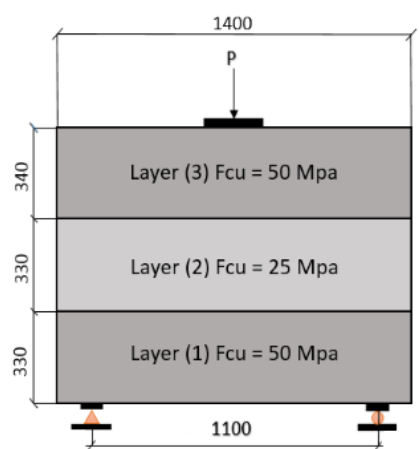

Figure 3-d: Specimen dimensions and compressive strength for (B4)

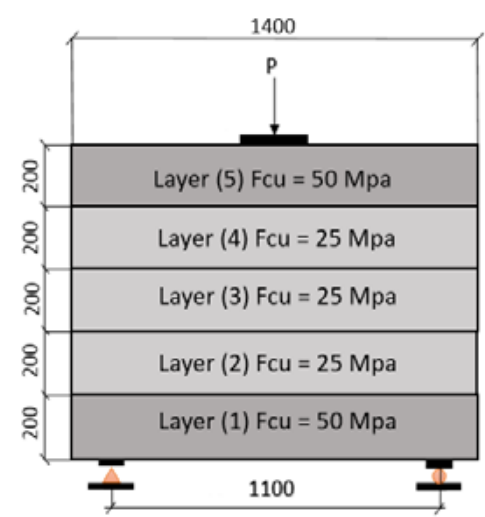

Figure 3-e: Specimen dimensions and compressive strength for (B5) 
ISSN (online): 2581-3048

Volume 5, Issue 8, pp 75-81, August-2021

https://doi.org/10.47001/IRJIET/2021.508013

\subsection{Material Properties}

a. Concrete 25 MPa: Concrete mix was designed to obtain an average cube compressive strength of $25 \mathrm{MPa}$. The concrete mix design by weight $(\mathrm{Kg} / \mathrm{m} 3)$ is $10 \mathrm{~mm}$ coarse aggregates $(1200 \mathrm{Kg})$, fine coarse aggregates "sand" (800 Kg), cement $(300 \mathrm{Kg})$, and water $(150 \mathrm{Kg})$.

b. Concrete 50 MPa: Concrete mix was designed to obtain an average cube compressive strength of $50 \mathrm{MPa}$. The concrete mix design by weight $(\mathrm{Kg} / \mathrm{m} 3)$ is $10 \mathrm{~mm}$ coarse aggregates $(1180 \mathrm{Kg})$, fine coarse aggregates "sand" (620 Kg), cement $(500 \mathrm{Kg})$, and water $(190 \mathrm{Kg})$, sika fume $(75 \mathrm{Kg})$, and sikament R4PN (14 Kg).

c. Reinforcement: High strength steel with grade of $\mathrm{P}$ 400/600 (Fproof $400 \mathrm{MPa}$ ) with elastic Modulus $=200000$ $\mathrm{MPa}$. The reinforcement diameter bars used are $10 \mathrm{~mm}, 12 \mathrm{~mm}$, and $16 \mathrm{~mm}$. Table 2 shows the mechanical properties of the reinforcement.

Table 2: Mechanical properties of the reinforcement

\begin{tabular}{|c|c|c|c|}
\hline $\begin{array}{c}\text { Bar diameter } \\
(\mathbf{m m})\end{array}$ & $\begin{array}{c}\text { Nominal area } \\
(\mathbf{m m})\end{array}$ & $\mathbf{F}_{\text {proof }}(\mathbf{M P a})$ & $\mathbf{F}_{\text {ult }}$ (Mpa) \\
\hline $\mathrm{T} 10$ & 78.5 & 544 & 654 \\
\hline $\mathrm{T} 12$ & 113 & 529 & 630 \\
\hline $\mathrm{T} 16$ & 201 & 413 & 620 \\
\hline
\end{tabular}

\subsection{Formwork}

A wooden formwork was used in manufacturing of tested specimens as shown in figure 4.

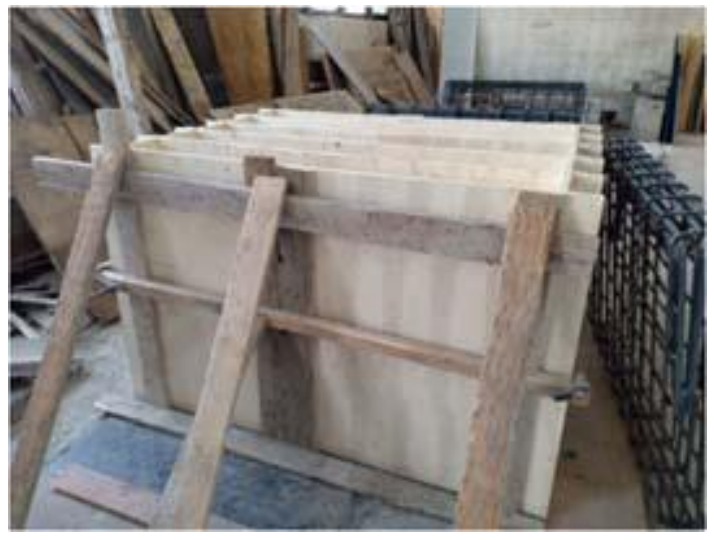

Figure 4: Preparation of formwork

\subsection{Fabrication of Test Specimens}

The reinforcement cages were assembled outside the formwork. Then placed inside the formwork before casting of concrete. Concrete is mixed using a rotating mixer. For specimens (B1 and B2) the casting of concrete was on one layer while for specimens (B3, B4, and B5) the casting of concrete was on different layers. The time period between each layer and the other was 24 hours, and before casting the new concrete layer, the surface of the old concrete was roughened and painted with adhesive material [Epoxy 104]. After casting every layer of the concrete in the wooden forms, the concrete is compacted using a hand-held mechanical vibrator to compact concrete in formwork and around reinforcement to ensure no honeycomb is formed. The sides of the form were removed after 24 hours of casting. The specimens were cured for ten days and covered by wet burlap to control the rate of moisture loss and hence prevent shrinkage cracking.
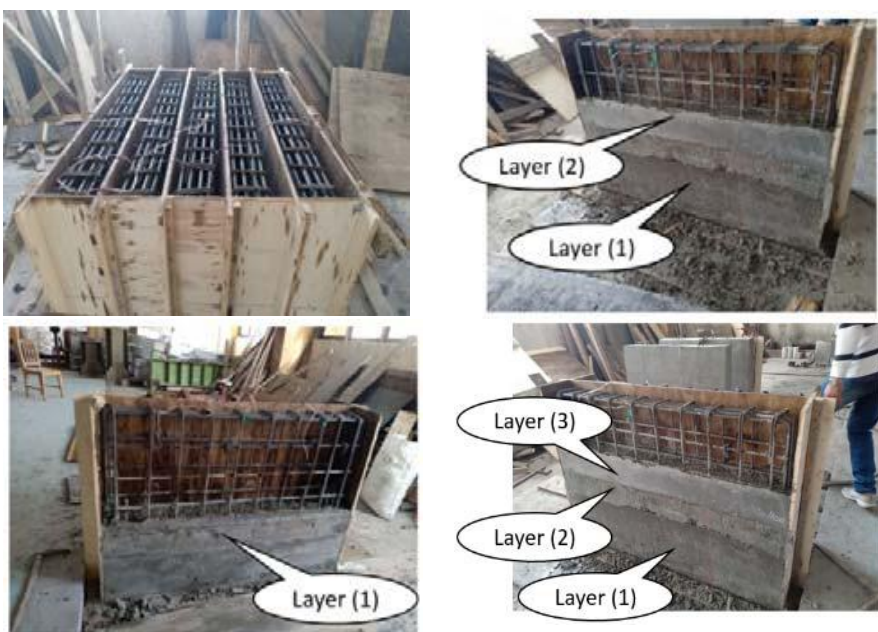

Figure 5: Placement of reinforcement and casting concrete on different layers

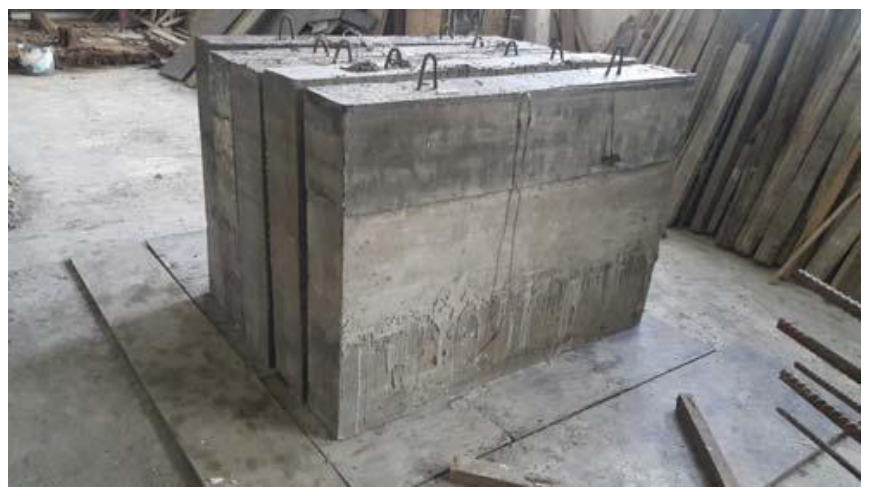

Figure 6: Removing of formwork After 10 Days from casting date

\subsection{Test setup and loading program}

The tested deep beams were simply supported using steel plates rested above rigid steel columns which are fixed to the ground and capable of carrying vertical loads at both ends. Figure 7 shows specimen testing and loading setup components. A Load cell attached to a hydraulic jack and connected to a data acquisition system to measure generated loads during the test. Actual displacements were measured 
ISSN (online): 2581-3048

using an LVDT "linear variable differential transducers". The LVDT were installed on the bottom of the specimen at mid span and fixed to a nonmovable base. Steel bearing plates were used, the top bearing plate had dimensions $400 \mathrm{~mm} \mathrm{x}$ $200 \mathrm{~mm}$ and $30 \mathrm{~mm}$ thickness under acting concentrated load. While the bottom two plates with dimensions $200 \mathrm{~mm} \times 150 \mathrm{~mm}$ and $25 \mathrm{~mm}$ thickness were used at the supports to avoid the local failure at disturbance regions under load and supports. The testing of the deep beams was performed using a loading frame with a $2200 \mathrm{kN}$ capacity hydraulic jack. The load was applied vertically according to the pre-assigned increments. At each increment, the mid-span deflection, strains on main steel were measured.

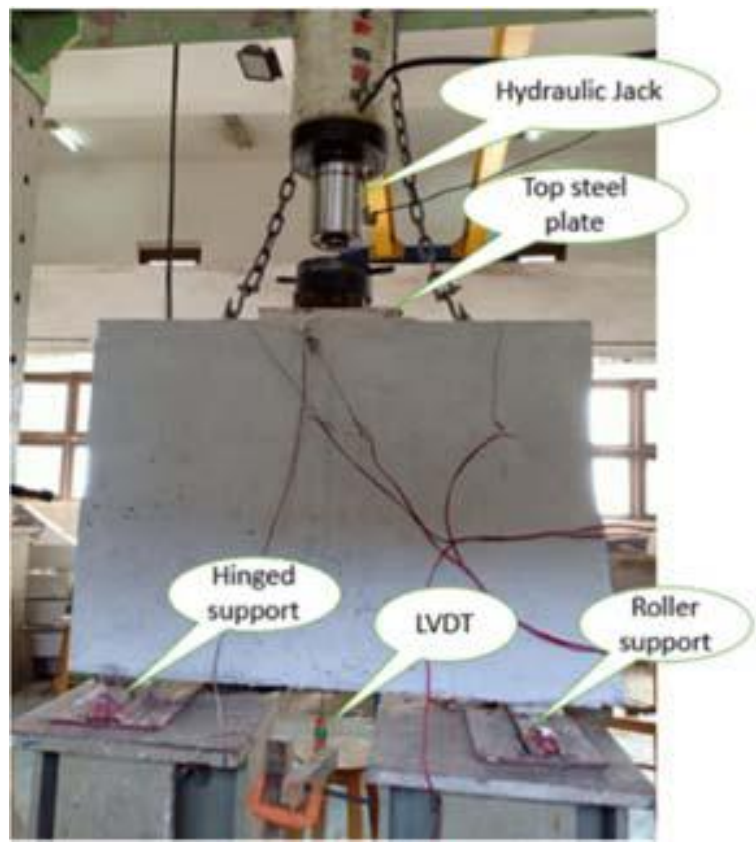

Figure 7: Test and loading setup for tested specimens

\subsection{Instrumentation}

Four types of instrumentations were used to collect and record data during each test:

a. Load cell: A Load cell was placed between the hydraulic jack and the deep beam to measure the applied load on the beam with a maximum capacity equal to $2200 \mathrm{kN}$.

b. LVDT's: One Linear Variable Differential Transducers (LVDT) was used to measure the displacement. Displacement transducers are the main devices used for measuring the imposed and resulting displacements in the tests. The linear variable differential transducers (LVDT) of maximum gauge length of $100 \mathrm{~mm}$ and precision of $1 / 100$ of $\mathrm{mm}$ are located vertically at the mid-span bottom surface of the specimen. Location of LVDT's as shown in figure 8.
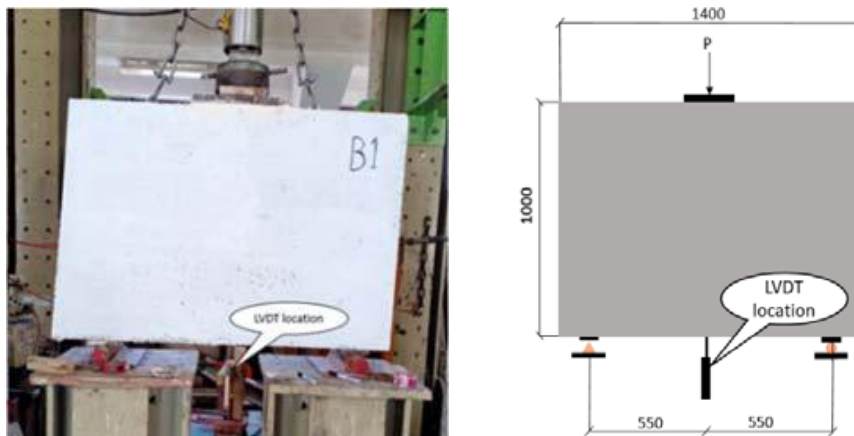

Figure 8: Location of LVDT in the specimen

c. Strain Gauges: Electrical strain gauges were used for measuring the strain at different locations throughout the tests. Electrical resistance strain gauges with $6 \mathrm{~mm}$ gauge length were attached to reinforcement bars before it had been placed in the formwork. One strain gauge was installed at bottom reinforcement at mid span, two strain gauges were installed at stirrups near supports and one strain gauge installed to middle side bar at mid span. The strain gauges are installed at the location of the maximum stress of the steel reinforcement to measure strain in the steel. Locations of strain gauges on steel bars for all specimens are shown in figure 9 .
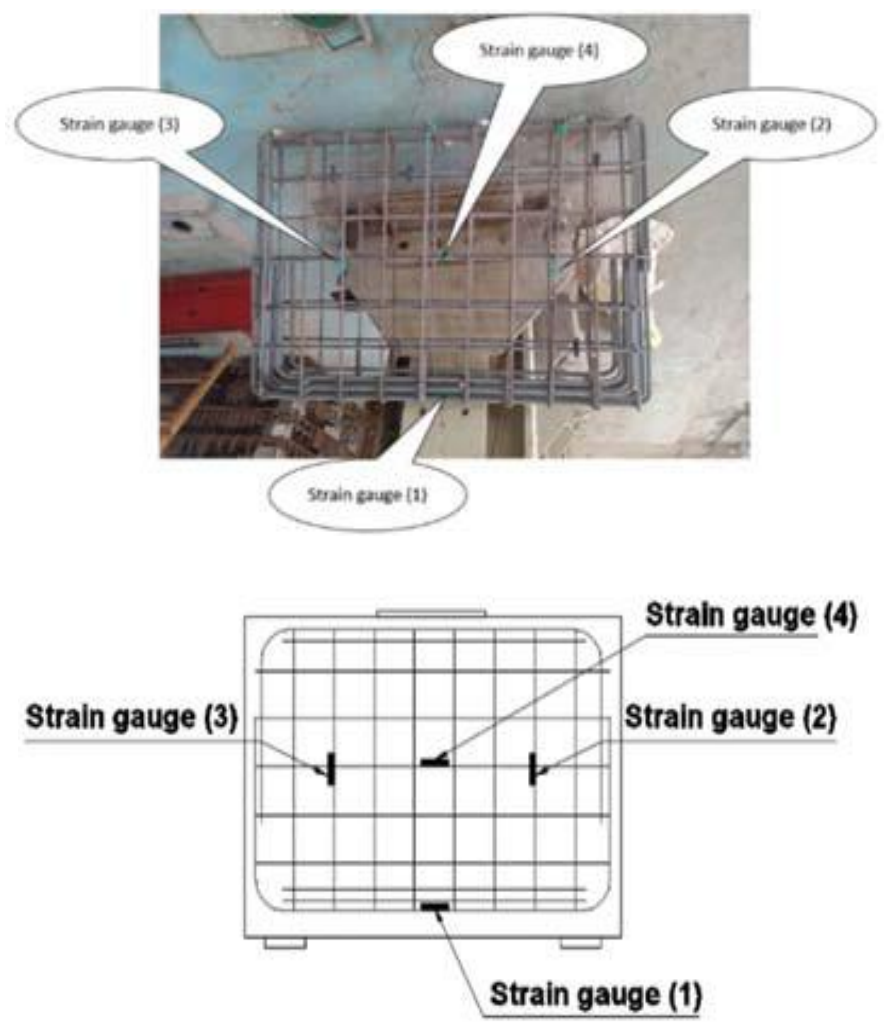

Figure 9: Locations of the steel strain gauges in all specimens

d. Data Acquisition: All the required data were recorded by the data acquisition appliance, at which all the LVDTs and electrical strain gauges of the experiment were connected to the adequate number of channel boxes. 


\section{RESULTS AND DISCUSSIONS}

\subsection{Crack Pattern and Failure Mode}

The observed behavior under the applied concentrated vertical load for the tested deep beams indicated that the first crack was a vertical one initiated at the middle bottom of the beam web at a load $1000 \mathrm{kN}, 1700 \mathrm{kN}, 650 \mathrm{kN}, 700 \mathrm{kN}$, and $700 \mathrm{kN}$ for $\mathrm{B} 1, \mathrm{~B} 2, \mathrm{~B} 3, \mathrm{~B} 4$, and $\mathrm{B} 5$ respectively. It is noticeable that first crack appeared for B3, B4, and B5 at load less than B1 and B2, this is due to casting concrete on different layers which causes the specimen to be nonhomogeneous because of the different modulus of elasticity (Young's modulus E), and the coefficient of friction between different layers of concrete. With the increase in loading, additional flexural cracks were developed in the mid-span. At a later stage, cracks along the lines of load paths, (the lines join between point of load application and beam supports), were detected.

These cracks were located at mid height of the specimen and then, with the increase of load, they extended towards the supports leading to failure at load $1770 \mathrm{kN}, 2200 \mathrm{kN}, 1700$ $\mathrm{kN}, 2100 \mathrm{kN}$, and $2000 \mathrm{kN}$ for B1, B2, B3, B4, and B5 respectively (for $\mathrm{B} 2$ the failure not occurred and this load corresponding to maximum load cell). As shown in Figures 10-a to 10-e the failure for B1 (compression failure), for B2 (failure not occurred), for B3 (bearing failure), for B4 (bearing+ compression), and for B5 (bearing + compression failure).
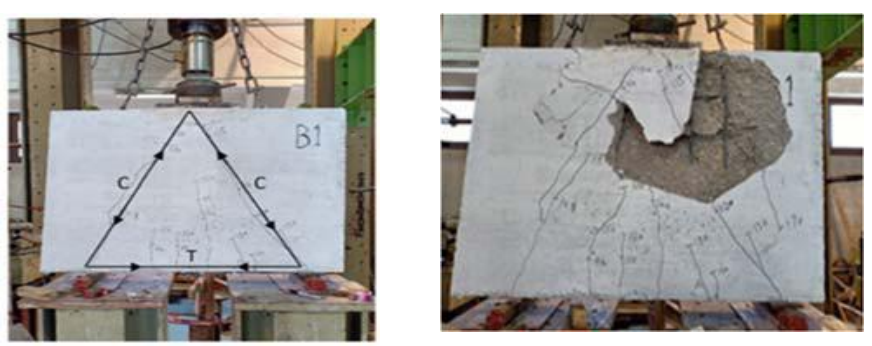

Figure 10-a: Crack pattern at maximum load cell for specimen (B1)
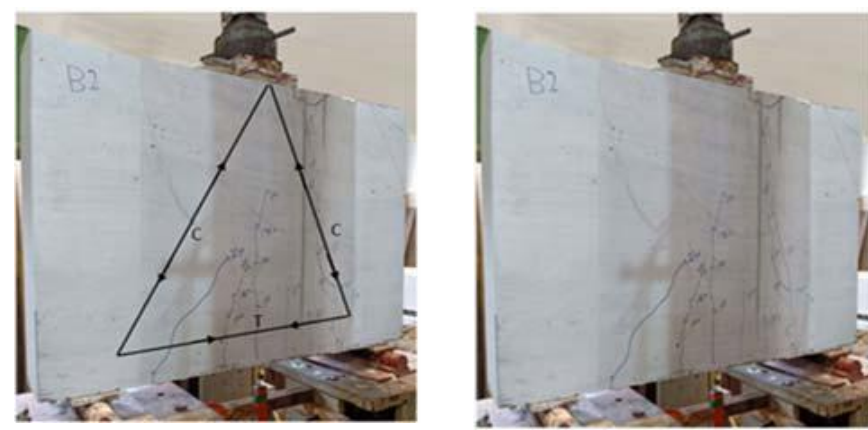

Figure 10-b: Crack pattern at maximum load cell for specimen (B2)
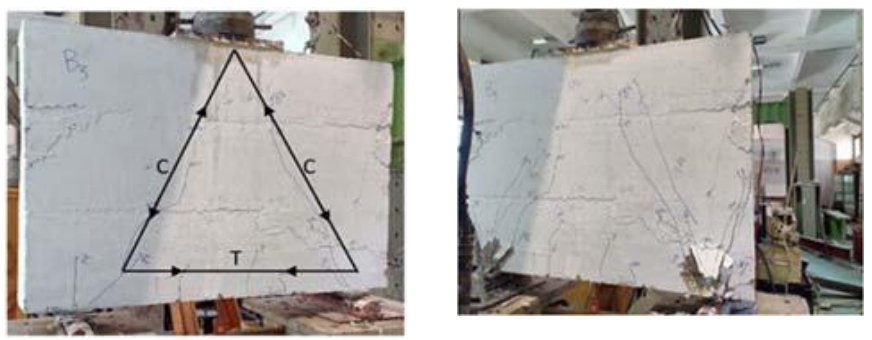

Figure 10-c: Crack pattern and failure mode for specimen (B3)
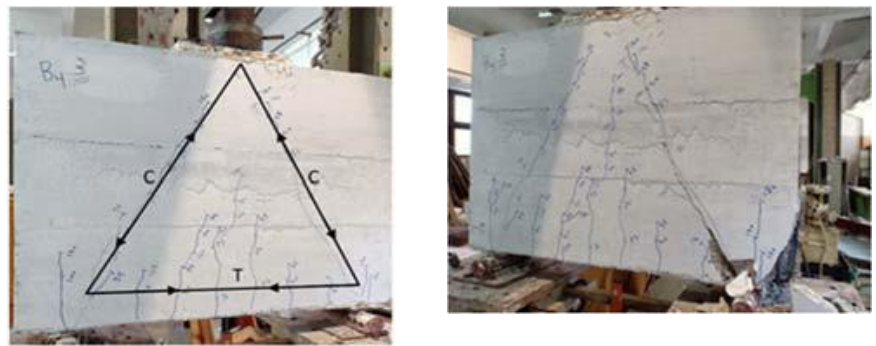

Figure 10-d: Crack pattern and failure mode for specimen (B4)
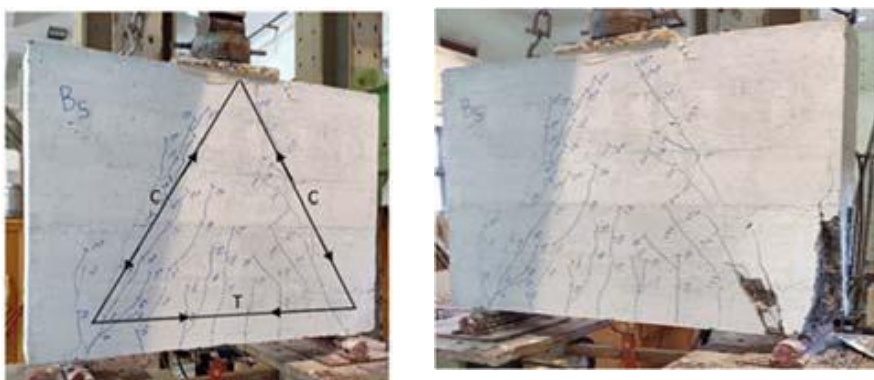

Figure 10-e: Crack pattern and failure mode for specimen (B5)

\subsection{Experimental Failure Load}

The summary of the experimental test results is shown in Table 3.

Table 3: Summary of experimental result

\begin{tabular}{|c|c|c|c|c|}
\hline Specimens & $\begin{array}{c}\text { Cracking load } \\
(\mathrm{KN})\end{array}$ & $\begin{array}{c}\text { Failure load } \\
\text { (KN) }\end{array}$ & Pcr/Pu & Mode of failure \\
\hline B1 & 1000 & 1770 & 0.56 & Compression failure \\
\hline B2 & 1700 & $\begin{array}{c}2200 \text { (Max. Load } \\
\text { cell) }\end{array}$ & 0.77 & failure not occurred \\
\hline B3 & 650 & 1700 & 0.38 & Bearing failure \\
\hline B4 & 700 & 2100 & 0.33 & $\begin{array}{c}\text { Bearing + Compression } \\
\text { failure }\end{array}$ \\
\hline B5 & 700 & 2000 & 0.35 & $\begin{array}{c}\text { Bearing + Compression } \\
\text { failure }\end{array}$ \\
\hline
\end{tabular}

\subsection{Deformations of tested specimens}

The load-vertical deflection behavior at mid span. Deflection was recorded with load increment and up-till specimen's failure. As shown in figure 11 the maximum deflection is $3.0 \mathrm{~mm}, 1.38 \mathrm{~mm}$ (corresponding to maximum load cell), $2.45 \mathrm{~mm}, 2.1 \mathrm{~mm}$, and $2.6 \mathrm{~mm}$ for specimens B1, B2, B3, B4 and B5 respectively. It should be noted that the increase in concrete compressive strength resulted in less 
ISSN (online): 2581-3048

deflection. For B3 it was found that using high compressive strength concrete at the top layer (compression zone) resulted in less deflection by $25 \%$ less than the maximum deflection of specimen B1. For B4 using high compressive strength concrete at the top and bottom layers (compression and tension zones) resulted in less deflection by $43 \%$ less than the maximum deflection of specimen B1. For B5 It was noticed that using high compressive strength concrete at the top and bottom layers (compression and tension zones) but with thickness less than specimen B4 resulted in less deflection by $15 \%$ less than the maximum deflection of specimen B1.

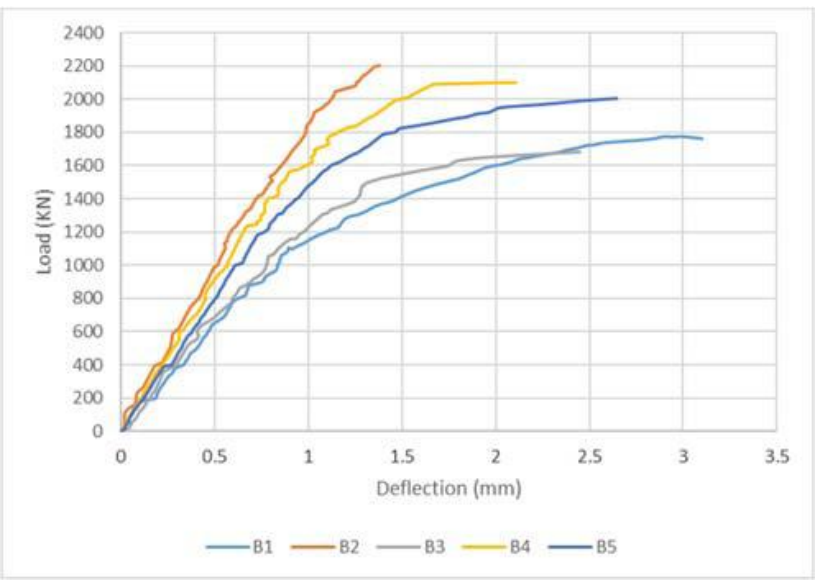

Figure 11: Load - deflection behavior for all tested specimens

\subsection{Steel Strain behavior in tension reinforcement for tested specimens}

Electrical strain gauges were used for measuring the strain. One strain gauge was installed to bottom reinforcement at middle span. The strain gauges are installed at the location of the maximum stress of the steel reinforcement to measure strain in the steel. As shown in Figure 12 the bottom reinforcement did not reach to yield stress because all specimens designed to failure in the concrete, and it should be noted that the increase in concrete compressive strength resulted in less strain.

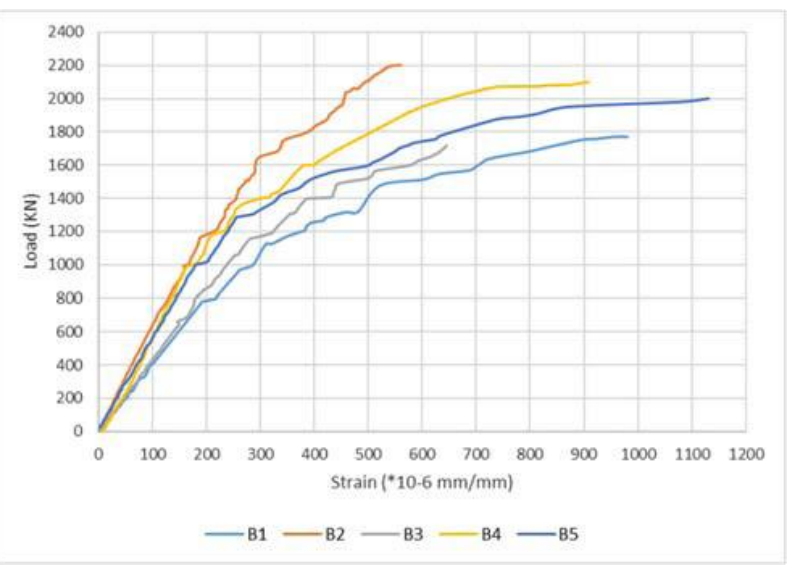

Figure 12: Load versus tension steel strain for all tested specimens

\section{CONCLUSION}

- Failure of tested deep beams was mainly due to diagonal cracking and it was along the lines joining the loading points and supports.

- Changing compressive strength of concrete from 25 $\mathrm{MPa}$ to $50 \mathrm{MPa}$ results in less deflection, higher value of cracking load and a higher failure load.

- Casting concrete on different layers causes the specimen to be non-homogeneous because of the different modulus of elasticity (Young's modulus E ), Poisson's ratio $v$, and the coefficient of friction between different layers of concrete So the cracks appeared at early stage (B3, B4, and B5) than casting concrete on one layer (B1 and B2).

- The best flexural behavior of deep beams is obtained when the bottom layer is casted using high concrete compressive strength and gives results (deflection, and failure load) close to result from deep beam casted with fully high compressive strength beam. This is due to the tension stiffness of concrete at the time zone which adds additional tension force added to tension at the bottom steel reinforcement and leads to less strain.

\section{REFERENCES}

[1] Nilson, A. H., and Darwin, D., "Design of Concrete Structures," McGraw-Hill International Editions, $12^{\text {th }}$ Edition, 1997, pp. 151.

[2] Russo, G., Venir, R., and Pauletta, M., "Reinforced Concrete Deep Beams-Shear Strength Model and Design Formula," ACI Structural Journal, Vol. 102, No.3, May-June, 2005, pp. 429-437.

[3] de Paiva, H. A. R., and Siess, C. P., "Strength and Behavior of Deep Beams in Shear," Journal of the Structural Division, ASCE, V. 91, No. ST5, Oct. 1965, pp. 19-41.

[4] Smith, K. N., and Vantsiotis, A. S., "Shear Strength of Deep Beams, ACI JOURNAL, Proceedings V. 79, No. 3, May-June 1982, pp. 201-213.

[5] Egyptian Standard "Egyptian Code of Practice for Design of Reinforced Concrete Structures (ECP 203)", published in 2020.

[6] American Concrete Institute "Building Code Requirements for Structural Concrete (ACI 318-19)", published in 2019.

[7] Ghoneim, M., "Shear Strength of High Strength Concrete Deep Beams." Journal of Engineering and Applied Science, Fculty of Engineering, Cairo University, V. 48, No. 4, Aug. 2001, pp 674-693. 
ISSN (online): 2581-3048

Volume 5, Issue 8, pp 75-81, August-2021 https://doi.org/10.47001/IRJIET/2021.508013

[8] Oh, J. K., and Shin, S. W., "Shear Strength of Reinforced High Strength Concrete Deep Beams.” ACI Structural Journal, V.98, No. 2, 2001, pp 164-172.

[9] Tan, K. H., Kong, F. K., Teng, S., and Guan, L., "High Strength Concrete Deep Beams with Effective Span and Shear Span Variations." ACI Structural Journal, V.92, No. 4, 1995, pp 395-405.

[10] Foster, S. J., and Gilbert, R. I., "Experimental Studies on High- Strength Concrete Deep Beams," ACI Structural Journal, V. 95, No. 4, July-Aug. 1998, pp. 382-390.

\section{AUTHORS BIOGRAPHY}

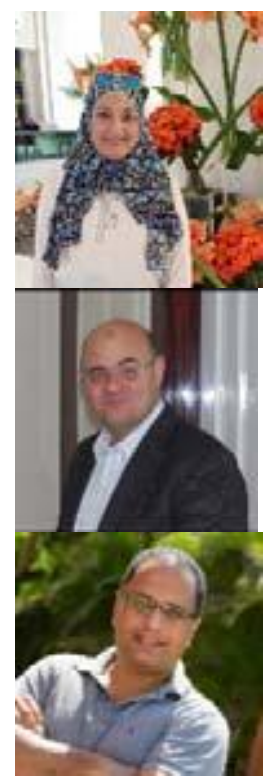

Noha Ahmed Metwally Ahmed Senior structural engineer, Faculty of engineering, Ain Shams University, Egypt, Email: eng.nohacivil@gmail.com

Prof. Ayman Hussein Hosny Khalil Professor of concrete structures at Ain Shams University, Egypt, E-mail: Ayman.hussein.khalil@eng.asu.edu.eg

Dr. Ezz EL-deen mostafa is an Assistant professor of concrete structures at Ain Shams University, Egypt, E-mail:

Ezzeldin.mostafa@eng.asu.edu.eg

\section{Citation of this Article:}

Noha Ahmed Metwally Ahmed, Prof. Ayman Hussein Hosny Khalil, Dr. Ezz El-deen Mostafa, "Behavior of Deep Beams using Different Concrete Grades" Published in International Research Journal of Innovations in Engineering and Technology - IRJIET, Volume 5, Issue 8, pp 75-81, August 2021. Article DOI https://doi.org/10.47001/IRJIET/2021.508013 